\title{
Seismic Fragility Curves for Tall Concrete Wall Building in Malaysia Subjected to Near-Field Earthquakes
}

\author{
Kotaiba Aljwim', Sophia C. Alih' ${ }^{2}$ Mohammadreza Vafaei ${ }^{3}$ and Siti Aisyah ${ }^{4}$ \\ ${ }^{1}$ School of Civil Engineering, Faculty of Engineering, Universiti Teknologi Malaysia, 81310, Johor, Malaysia. \\ ${ }^{2}$ Institute of Noise and Vibration, School of Civil Engineering, Faculty of Engineering, Universiti Teknologi Malaysia, \\ 81310, Johor, Malaysia. \\ ${ }^{3}$ School of Civil Engineering, Faculty of Engineering, Universiti Teknologi Malaysia, 81310, Johor, Malaysia. \\ ${ }^{4}$ School of Civil Engineering, Faculty of Engineering, Universiti Teknologi Malaysia, 81310, Johor, Malaysia.
}

ORCIDs: 0000-0003-3035-745X (Kotaiba), 0000-0001-5326-3670 (Sophia), 0000-0002-9988-1842 (Sophia), 0000-0002-1074-1932 (Siti)

\begin{abstract}
Tall buildings have been widely constructed in Malaysia, and most of them have been designed only for gravity and wind loads. This study addresses the seismic vulnerability of two tall concrete wall buildings in Malaysia through the framework of seismic fragility curves. The studied buildings shared a similar plan, but the first building had five parking levels while the second building had three parking levels. The structural system of both buildings at the parking levels was an ordinary moment-resisting frame, and at the residential levels was a low-ductile concrete shear wall system. The reference structures were subjected to 15 near-field earthquake records. Fragility curves were obtained by relating the inter-story drift demands to the peak ground accelerations using a reliable statistical model. It was observed that in both buildings, the probability of exceeding minor damage to the exterior frame was larger than that of the interior frame. Besides, a decrease in the number of parking levels increased the probability of collapse. It was also found that only minor damage was expected for tall concrete wall buildings in Kuala Lumpur when subjected to near-field earthquakes.
\end{abstract}

Keywords: Concrete wall, Fragility curves, Incremental dynamic analysis, Seismic damage, Tall buildings

\section{INTRODUCTION}

Buildings in Malaysia are mostly constructed by reinforced concrete. Many such buildings are designed to carry only the wind and gravity loads without considering seismic forces. Assessment of the vulnerability of these buildings is essential for predicting the potential earthquake losses. Malaysia's seismic hazard is characterized by far-field events from Sumatra and near-field events due to local seismic faults [1]. The recent earthquake in Ranau [2] drew attention to the prediction and mitigation of earthquake losses. Fragility relations are one of the essential tools in the risk assessment field and an effective approach to evaluate the performance of different structures under various levels of seismic intensities [3]. Fragility curves describe the probability of exceeding certain limit states under various ground motion scenarios [4]. Empirical, experimental, analytical, and combined approaches have been used to develop seismic fragility curves.

Fragility curves developed by the empirical method are based on observations from previous earthquakes. A very dense data is required to establish the relationship between structural damage and ground motions' intensity. The experimental method is employed to derive fragility curves as an alternative to the empirical method when the observational data cannot cover all characteristics of buildings [5,6]. More accurate fragility curves can be obtained using experimental tests but this method consumes a lot of time and cost [4]. The derivation of fragility curves using the analytical method is the most popular because it saves time and money [4]. In this method, finite element models are established and subjected to earthquake records. The analytical method has been employed by several researchers to develop fragility curves of different types of structures including ATC towers [7], bridges [8], tunnels [9], wind turbine [10], reinforced concrete chimneys [11], process towers [12], and masonry structures [13]. The hybrid method produces a realistic estimation for earthquake damage. In this method, both experimental and analytical techniques are combined to verify each other [14]. This combination can solve the problem of limited data and increase the efficiency of the analytical method [15].

During the past decades, Malaysia's construction industry has not taken into account the anti-seismic regulations [16]. In 2015, Ranau, located in East Malaysia, was stricken by an earthquake with a magnitude of 5.9. Several buildings were damaged due to the Ranau earthquake since many of them had been designed only for gravity and wind loads. Few studies have been conducted to evaluate the seismic performance of different structures in Malaysia [17,18]. These studies are limited to low-to-medium rise concrete buildings in Malaysia and often concentrate on far-field earthquakes [19]. The current study focuses on the development of seismic fragility curves for tall concrete wall buildings in Malaysia when subjected to near-field earthquakes. For this purpose, two reference buildings were designed according to the building 
codes adopted in Malaysia. The reference structures are discussed in detail in the next section.

\section{THE REFERENCE STRUCTURES AND THEIR FINITE ELEMENT MODELS}

The investigated structures are two reinforced concrete buildings with the same plan but with two different configurations along the height. The first five stories in the building (A) are assumed to be the parking area while the first three stories of the building (B) are parking areas. Each building consists of 25 stories with $3.2 \mathrm{~m}$ story height. Fig. 1 shows the plan of the selected buildings. At the parking levels, the plan's size is $36 \times 34 \mathrm{~m}$, and, at the residential levels, it is $36 \times 20 \mathrm{~m}$.

As shown in Fig.2, the finite element models of structures were developed in ETABS [20] software. These models were used to determine the sizes of beam and columns under the applied gravity and wind loads. Both buildings are designed following the provisions and recommendations of BS8110 [21] for gravity loads and ASCE 7-10 [22] for wind loads. The seismic design regulations were not adopted in buildings' design because it is not practiced in Malaysia. In the design of the structural elements, the concrete compressive strength is assumed $40 \mathrm{MPa}$, and the yield strength of reinforcing steel is taken $460 \mathrm{MPa}$. The live load is $2 \mathrm{kN} / \mathrm{m}^{2}$ for the residential levels and $5 \mathrm{kN} / \mathrm{m}^{2}$ for parking levels. Finishing loads of 1.6 $\mathrm{kN} / \mathrm{m}^{2}$ and $1.18 \mathrm{kN} / \mathrm{m}^{2}$ are applied at residential and parking levels, respectively. Wind loads are estimated base on a basic wind speed of $33 \mathrm{~m} / \mathrm{s}$ and the exposure category $B$.

The beams in the parking levels have a rectangular crosssection with the sizes of $75 \times 70 \mathrm{~cm}$ and $55 \times 50 \mathrm{~cm}$. The columns have a square cross-section with sizes of $45 \times 45 \mathrm{~cm}$, $50 \times 50 \mathrm{~cm}, 60 \times 60 \mathrm{~cm}$, and $70 \times 70 \mathrm{~cm}$. The thickness of shear walls varies along the height from $100 \mathrm{~mm}$ to $150 \mathrm{~mm}$. The slab is $170 \mathrm{~mm}$ thick with adequate reinforcements to prevent any progressive collapse in a local punching failure event.

In the nonlinear analysis, four framing systems are selected to represent the two reference structures' behavior. Such idealization has also been done by other researchers to reduce the computational time and efforts [4]. Fig. 3 illustrates the 2D models used for the exterior and interior framing systems in both buildings. It is assumed that slabs transfer half of their load to the adjacent shear walls and beams. Besides, the vertical stiffness of slabs was calculated based on the 3D models and applied to the boundary elements of 2D frames. Incremental dynamic analysis (IDA) [23] was used to estimate the inter-story drift demands and capacities. Nonlinear behavior of shear walls was simulated by using inelastic fiber elements. The fiber element method has been successfully used for estimating the inelastic behavior of concrete shear walls by previous researchers [24-27]. The nonlinear response of beams and columns were simulated by the lumped plasticity model [28]. Plastic hinges were assigned to both ends of beams and columns. The typical force-deformation relationship of plastic hinges is shown in Fig. 4. In this figure, segment $\mathrm{AB}$ represents the elastic behavior, segment $\mathrm{BC}$ shows the post-yield behavior, and segment $\mathrm{CD}$ indicates the beginning of the failure. The modeling parameters and acceptance criteria of the plastic hinges were determined based on the recommendations of ASCE/SEI 41 [29], considering material properties, internal forces, and sizes of beams and columns.

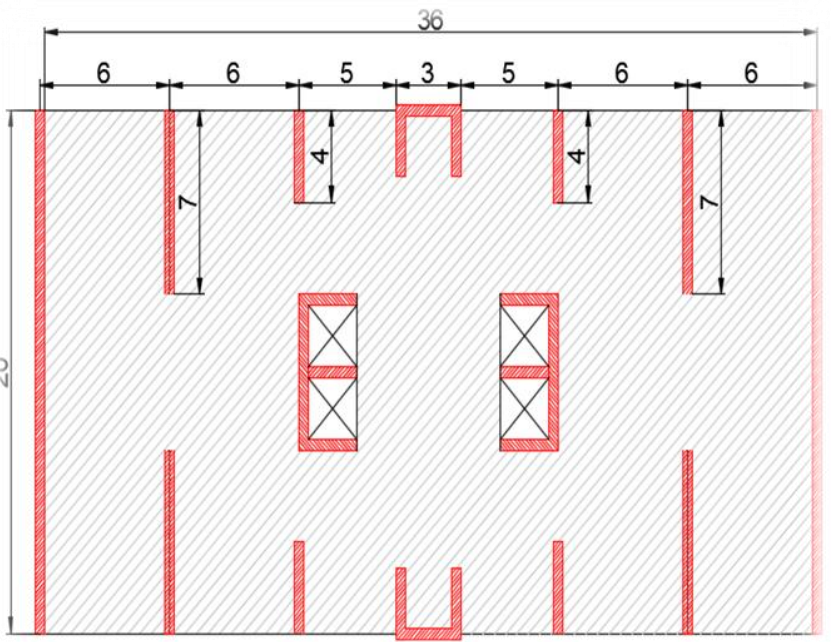

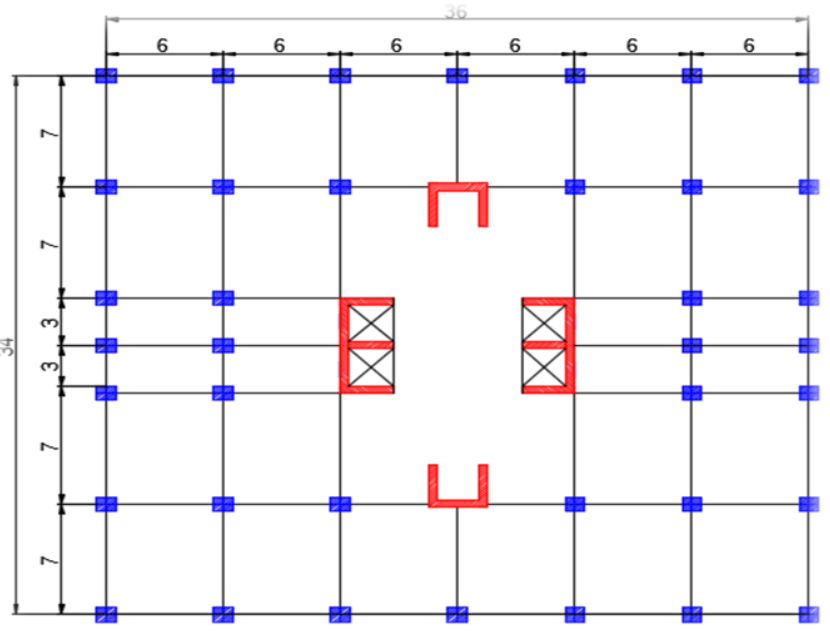

(a) (b)

Fig 1. Layout of the reference structures. a. Parking levels, b. residential levels 


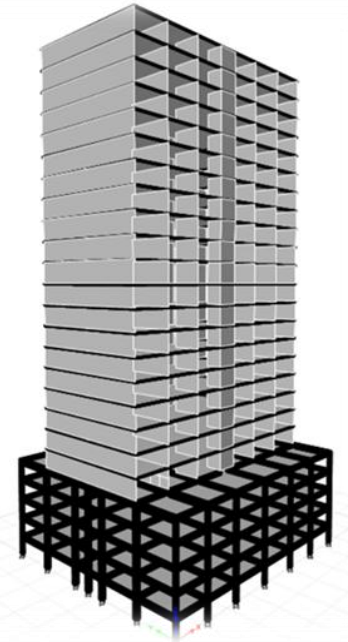

(a)

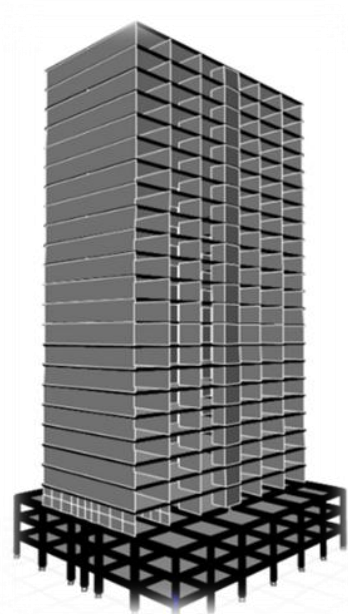

(b)

Fig 2. Finite element models of buildings a. Building (A), b. Building (B)

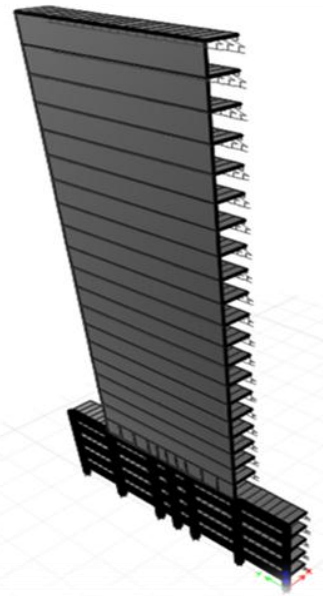

(a)

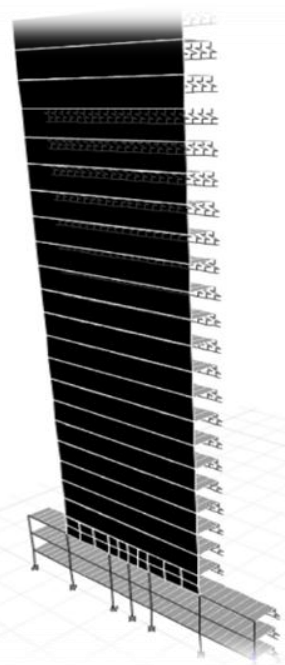

(c)

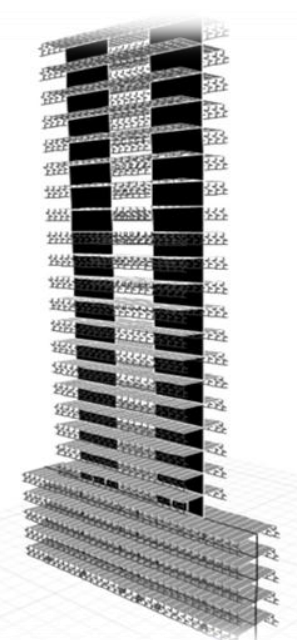

(b)

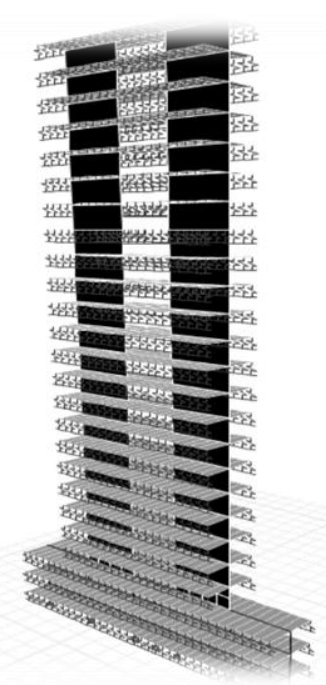

(d)

Fig 3. Nonlinear finite element models a. Exterior frame in building (A), b. Interior frame in building (A), c. Exterior frame in building (B), d. Interior frame in building (B) 


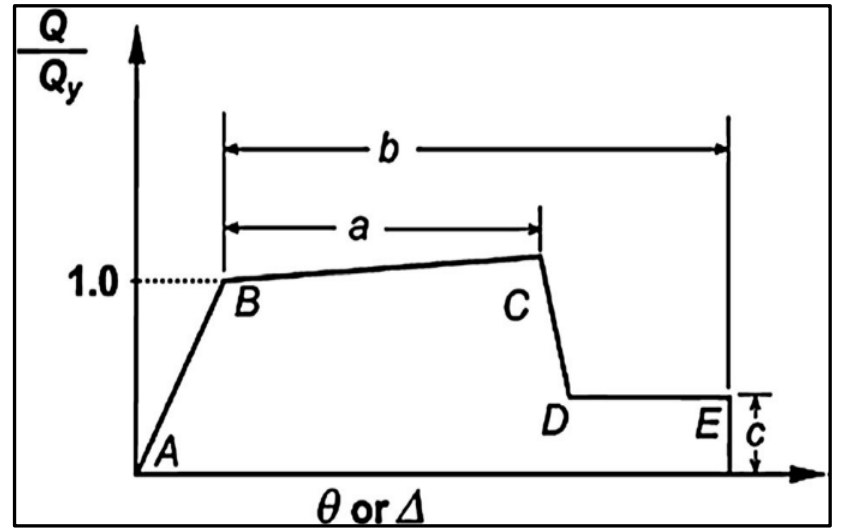

Fig 4. Generalized chord rotation model used for inelastic behaviour of beams and columns

\section{DERIVATION OF SEISMIC FRAGILITY CURVES}

It is not practical to identify all uncertain parameters that influence the seismic fragility curves. Therefore, often only the most important uncertain parameters that significantly impact seismic fragility curves are taken into account. Based on the study conducted by Kwon et al. [30], the variability in ground motions has more impact on seismic fragility relations than the material properties. Considering the study conducted by Kwon et al., the uncertainty in ground motions was only included in the development of fragility curves. Material properties were considered deterministic, and their mean values were used in this study. To capture the uncertainty in ground motions, 15 near-field natural earthquake records were selected to derive fragility curves for the reference structures. The details of the selected records can be found in the study conducted by Tso et al. [31].

For the derivation of seismic fragility curves, the following equations were employed [32]:

$P(D S \mid S I)=1-\phi\left(\frac{\lambda_{C}-\lambda_{\mathrm{D} \mid \mathrm{SI}}}{\sqrt{{ }^{{ }_{\mathrm{D} \mid \mathrm{SI}}{ }^{2}+\beta_{C}{ }^{2}+\beta_{M}^{2}}}}\right)$

$\beta_{\mathrm{D} \mid \mathrm{SI}}=\sqrt{\ln \left(1+S^{2}\right)}$

$\beta_{C}=\sqrt{\ln \left(1+\operatorname{Cov}^{2}\right)}$

where, $P(D S \mid S I)$ is the conditional probability of exceeding a limit state $(D S)$ for a given seismic intensity $(S I) . \phi$ is the standard normal distribution; $\lambda_{C}$ is the natural logarithm of the median of the drift capacity for a particular damage state; $\lambda_{\mathrm{D} \mid \mathrm{SI}}$ is the natural logarithm of calculated median demand drifts given the seismic intensity from the best fit power-law line. $S^{2}$ is the standard error and $\ln$ is the natural logarithm. $\beta_{\mathrm{D} \mid \text { SI }}$ stands for demand uncertainty while $\beta_{C}$ and $\beta_{M}$ show uncertainties associated with capacity and modeling, respectively. Cov. is the coefficient of variation of the calculated limit state capacities. In this study, $\beta_{M}$ is assumed to be 0.3 [4].

In the derivation of seismic fragility curves, three different damage limit states were used. The damage limit states followed the recommendation of ASCE/SEI 41 [29] and were inclusive of Immediate occupancy (IO), Life Safety (LS), and Collapse Prevention (CP). The structure can be reused immediately after an earthquake with minor damage to nonstructural components at the IO level. On the other hand, the LS level represents a medium level of damage to the structural elements. In the CP level, the structure is exposed to potential collapse. The acceptance criteria for different damage limit states of concrete and reinforcing bars are shown in Table 1. As mentioned earlier, the acceptance criteria for different damage limit states of plastic hinges followed the values given in ASCE/SEI 41 [29].

Table 1. Acceptance criteria for different damage limit states

\begin{tabular}{|c|c|c|}
\hline Damage state & $\begin{array}{l}\text { Strain in } \\
\text { concrete }\end{array}$ & $\begin{array}{l}\text { Strain in } \\
\text { reinforcement }\end{array}$ \\
\hline IO & 0.01 & 0.0025 \\
\hline LS & 0.02 & 0.02 \\
\hline $\mathrm{CP}$ & 0.005 & 0.05 \\
\hline
\end{tabular}

\section{RESULTS AND DISCUSSIONS}

Table 2 displays the median drift capacities obtained for exterior and interior frames in both buildings. As can be seen from the table, drift capacities obtained for the building (A) are larger than the building (B). Besides, the drift capacities of the exterior frames in both buildings are larger than the drift capacities of interior frames. It should be mentioned that no drift capacity was obtained for the LS limit state because the buildings exhibited a sudden transition from the IO level to CP limit states. This behavior relies on this fact that the buildings were not designed for seismic actions and therefore showed a brittle failure.

Fig. 5, Fig. 6, Fig. 7, and Fig. 8 depict the statistical distributions of inter-story drift ratios (IDRs) against PGAs and the calculated power-law equations and the correlation coefficient (R). The obtained results indicate strong correlations between the median drift demands obtained from the power-law equations and the PGAs of records. It can also be seen that compared with the interior frames, the exterior frames have relatively greater inter-story demand. Besides, the obtained inter-story demands for the building (A) are greater than the building (B).

Fig. 9 displays the developed fragility curves for the exterior frame in the building (A). The probability of exceeding the IO limit state at the PGA of $0.1 \mathrm{~g}$ in the exterior frame is around $10 \%$. However, it increases sharply to reach $90 \%$ at the PGA of $0.4 \mathrm{~g}$. On the other hand, the probability of exceeding the 
International Journal of Engineering Research and Technology. ISSN 0974-3154, Volume 13, Number 9 (2020), pp. 2205-2212

(C) International Research Publication House. https://dx.doi.org/10.37624/IJERT/13.9.2020.2205-2212

$\mathrm{CP}$ limit state in the exterior frame of the building (A) is around $3 \%$ when the PGA is less than $0.2 \mathrm{~g}$. Fig. 10 shows the fragility curves obtained for the interior frame of the building (A). It can be seen from the figure that the probability of exceeding the IO limit states is close to that of the CP limit state. This implies a sudden transition from minor damage to severe damage, which often occurs in low ductile structures. As the figure shows, the probability of exceeding the IO and CP limit states at the PGA of $1.0 \mathrm{~g}$ is less than $30 \%$ and $25 \%$, respectively. These observations also show that in the building (A), the exterior frame is more vulnerable than the interior frame.

The obtained seismic fragility curves for the exterior frame of the building (B) are presented in Fig. 11. As the figure shows, the probability of exceeding IO and CP limit states when the PGA is $0.1 \mathrm{~g}$ is below 5\%. However, when the PGA equals $0.2 \mathrm{~g}$, the probability of exceeding the IO limit states reaches $10 \%$, and that of $\mathrm{CP}$ limit states approaches to $5 \%$. The probabilities of exceeding IO and CP limit states at the PGA of $1.0 \mathrm{~g}$ raise to $90 \%$ and $70 \%$, respectively. The obtained fragility curves for the interior frame of the building (B) are shown in Fig. 12. Similar to the building (A), for the entire range of PGAs, the probability of exceeding the IO limit states is close to that of the $\mathrm{CP}$ limit state. Fig. 12 also shows that for PGAs less than $0.2 \mathrm{~g}$, the probability of exceeding the IO and CP limit states is below 5\%. However, when the PGA approaches $1.0 \mathrm{~g}$, the probability of exceeding the IO and $\mathrm{CP}$ limit states reach, respectively, $80 \%$ and $75 \%$ at $1.0 \mathrm{~g}$. In the building (B), both frames show a similar probability for exceeding the CP limit state. Comparison between Fig. 11 and 12 show that the probability of exceeding the IO limit state in the exterior frame of the building (B) is larger than that of the interior frame. However, the probability of exceeding the $\mathrm{CP}$ limit state in both frames is close to each other.

It should be mentioned that the design PGA in Kuala Lumpur city for buildings constructed on the stiff and soft soil conditions are around $0.1 \mathrm{~g}$ and $0.15 \mathrm{~g}$, respectively [33]. Therefore, only minor damage is expected for tall concrete wall buildings located in this city and subjected to near-field earthquakes. Besides, an increase in the number of parking levels decreases the probability of exceeding severe damage to Malaysia's tall concrete wall buildings.

Table 2. Results of median drift capacities from IDA

\begin{tabular}{lllll}
\hline & \multicolumn{2}{l}{ Type of frame } \\
\cline { 2 - 5 } & \multicolumn{2}{l}{ Exterior frame } & \multicolumn{2}{l}{ Interior Frame } \\
\cline { 2 - 5 } & IO (\%) & $\mathrm{CP}(\%)$ & $\mathrm{IO}(\%)$ & $\mathrm{CP}(\%)$ \\
\hline Building (A) & 0.6 & 1.78 & 0.80 & 0.85 \\
\hline Building (B) & 0.9 & 1.1 & 0.49 & 0.52 \\
\hline
\end{tabular}

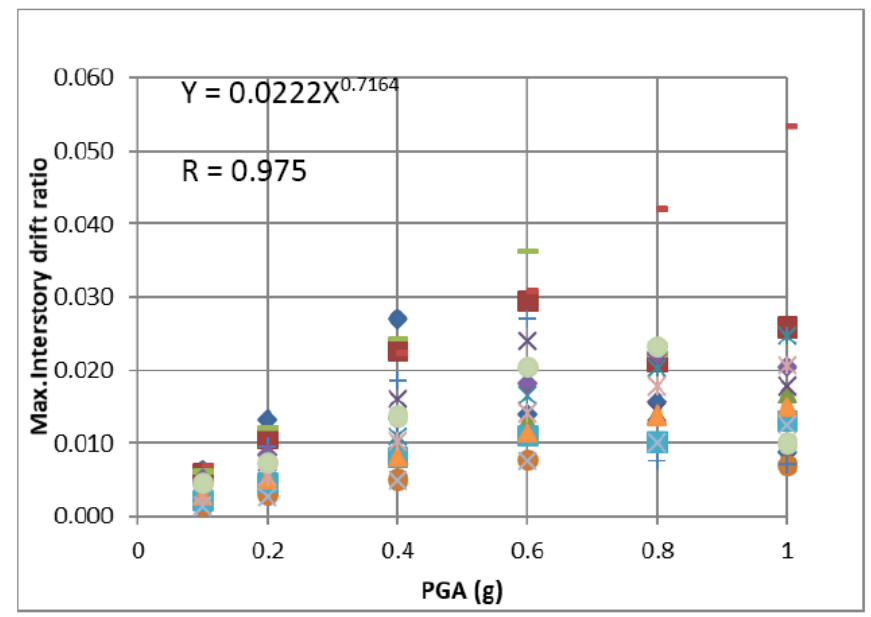

Fig 5. IDRs of exterior frame in building (A) against different ground motions

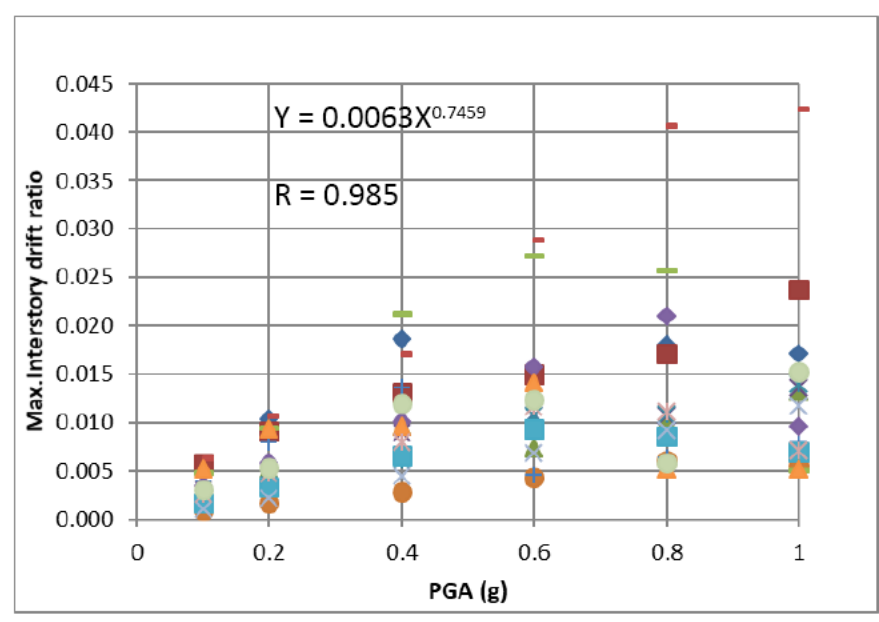

Fig 6. IDRs of interior frame in building (A) against different ground motions

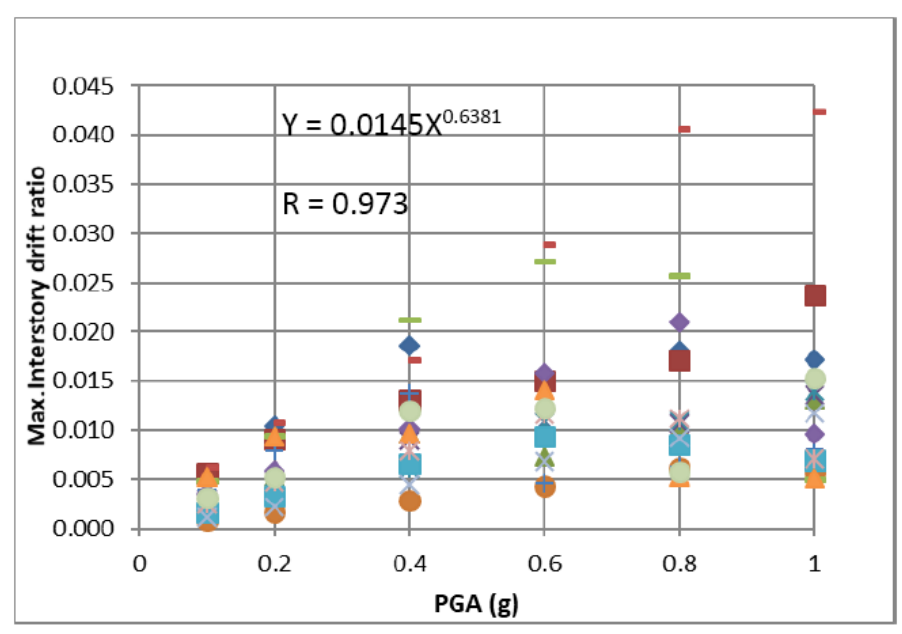

Fig 7. IDRs of exterior frame in building (B) against different ground motions 
International Journal of Engineering Research and Technology. ISSN 0974-3154, Volume 13, Number 9 (2020), pp. 2205-2212

(C) International Research Publication House. https://dx.doi.org/10.37624/IJERT/13.9.2020.2205-2212

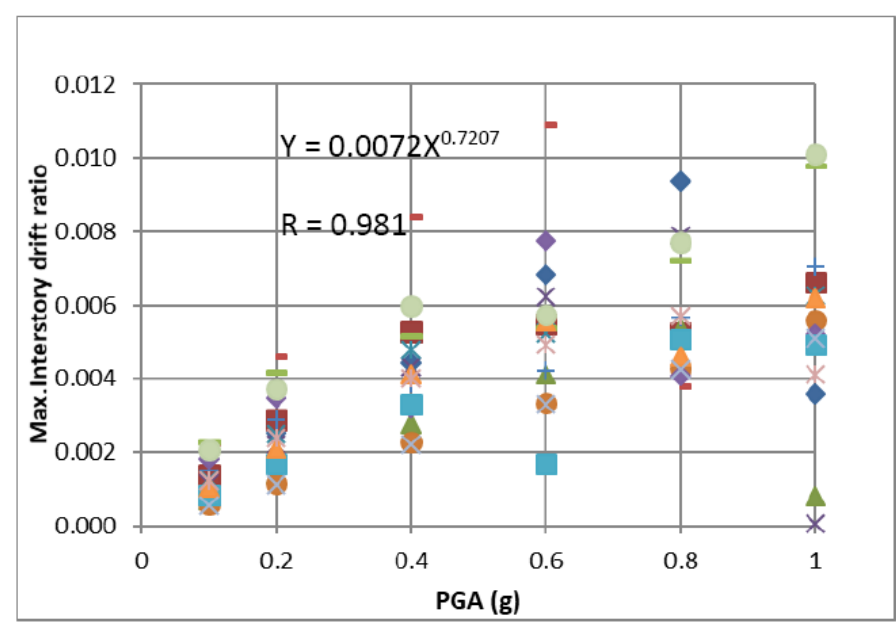

Fig 8. IDRs of interior frame in building (B) against different ground motions

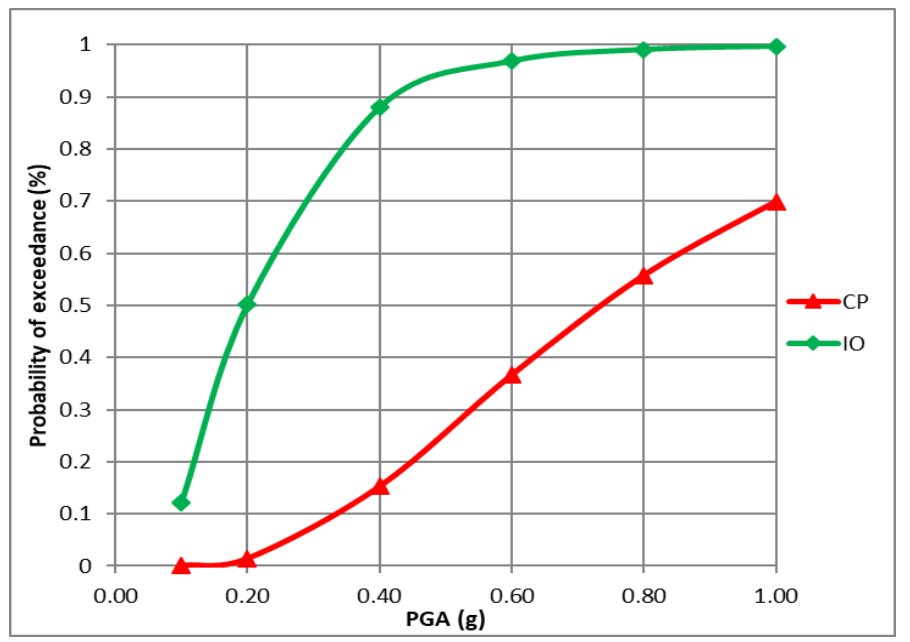

Fig 9. Seismic fragility curves for exterior frame in building (A)

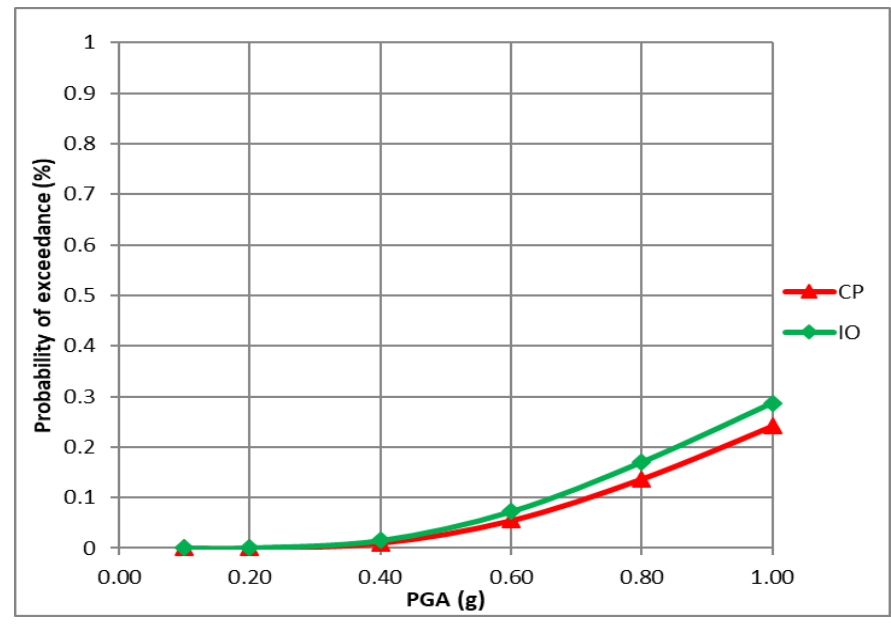

Fig 10. Seismic fragility curves for interior frame in building $(\mathrm{A})$

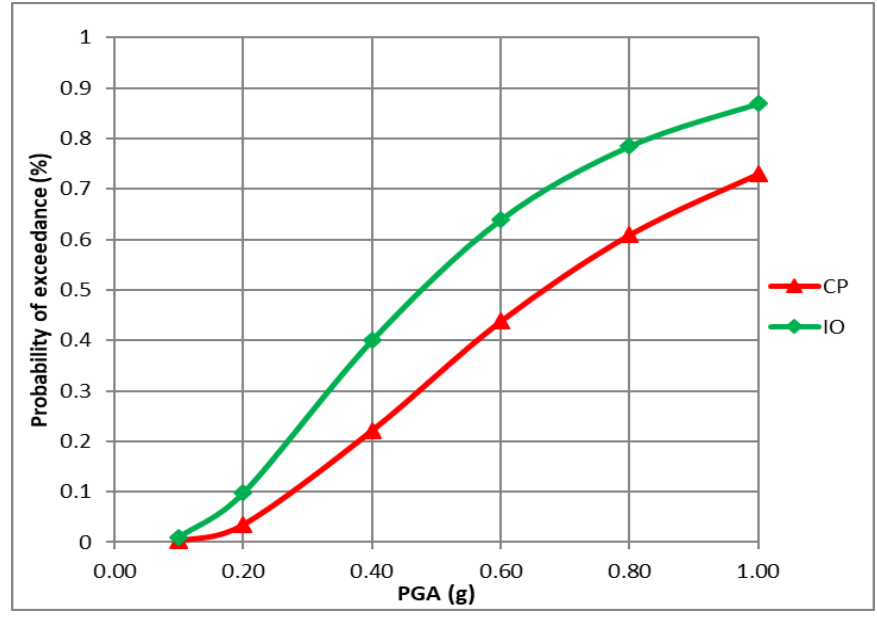

Fig 11. Seismic fragility curves for exterior frame in building (B)

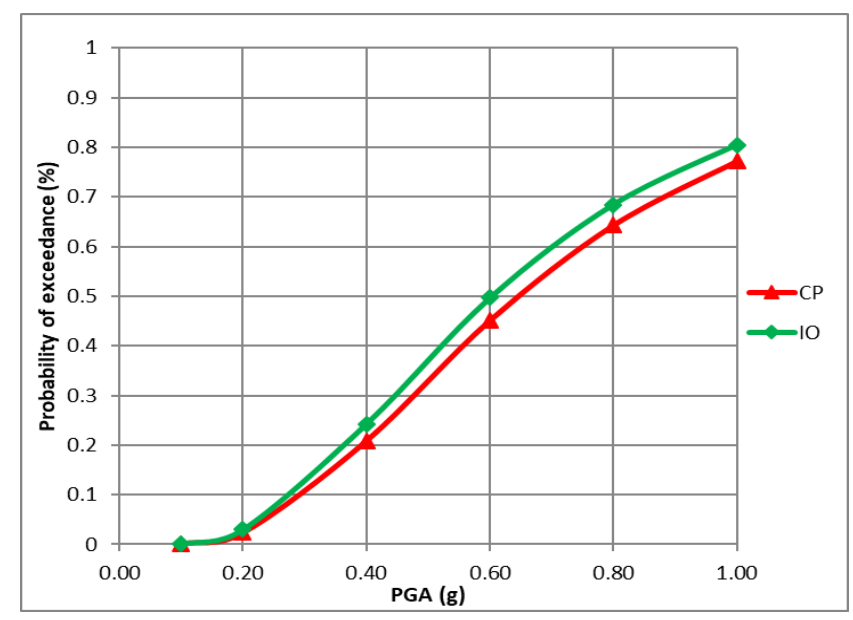

Fig 12. Seismic fragility curves for interior frame in building (B)

\section{CONCLUSION}

Many tall concrete wall buildings have been constructed in Malaysia. However, seismic design regulations have not been implemented in their design and construction. This study addressed the seismic fragility of two tall concrete wall buildings in Malaysia. Both buildings shared a similar plan and had 25 stories. The first five stories in the building (A) were designated to the car park area while in the building (B), the first three stories were designated as the car park. The lateral load resisting system of the car park levels was an ordinary moment-resisting frame, and that of the residential levels was low-ductile concrete shear walls. Buildings were designed only for the effects of gravity and wind loads. Four frames were extracted from the designed 3D buildings for the derivation of seismic fragility curves. The investigated frames included one interior and one exterior frame from each building and were subjected to 15 natural near-field earthquake records. The reference frames' fragile curves were obtained by relating the measured seismic responses from a 
large number of incremental dynamic analysis to the peak ground accelerations using a reliable statistical model. It was observed that the probability of exceeding minor damage in the building with five levels of parking was larger than the building with three levels of parking. In both buildings' exterior frames, the probability of exceeding minor damage was close to the probability of exceeding severe damage indicating a brittle failure mode. It was concluded that only minor damage was expected for tall concrete wall buildings located in Kuala Lumpur city when subjected to the near-field earthquakes.

\section{Acknowledgements}

The authors would like to thank the provided supports by Universiti Teknologi Malaysia (UTM). The financial support from the Ministry of Higher Education of Malaysia through the RUG votes of 16J24 and 4L705 are acknowledged

\section{REFERENCES}

[1] T. Balendra, Z. Li, Seismic hazard of Singapore and Malaysia, Electron. J. Struct. Eng. 8 (2008) 57-63.

[2] S.C. Alih, M. Vafaei, Performance of reinforced concrete buildings and wooden structures during the 2015 Mw 6.0 Sabah earthquake in Malaysia, Eng. Fail. Anal. $\quad 102 \quad$ (2019) 351-368. https://doi.org/10.1016/j.engfailanal.2019.04.056.

[3] G.M. Calvi, R. Pinho, G. Magenes, J.J. Bommer, L.F. Restrepo-Vélez, H. Crowley, Development of Seismic Vulnerability Assessment Methodologies over the past 30 Years, ISET J. Earthq. Technol. 43 (2007) 75-104.

[4] A. Mwafy, Analytically derived fragility relationships for the modern high-rise buildings in the UAE, Struct. Des. Tall Spec. Build. 21 (2012) 824-843. https://doi.org/10.1002/tal.642.

[5] E. Cosenza, L. Di Sarno, G. Maddaloni, G. Magliulo, C. Petrone, A. Prota, Shake table tests for the seismic fragility evaluation of hospital rooms, Earthq. Eng. Struct. Dyn. 44 (2015) 23-40. https://doi.org/10.1002/eqe.2456.

[6] G.H. Siqueira, A.S. Sanda, P. Paultre, J.E. Padgett, Fragility curves for isolated bridges in eastern Canada using experimental results, Eng. Struct. 74 (2014) 311324. https://doi.org/10.1016/j.engstruct.2014.04.053.

[7] M. Vafaei, S.C. Alih, Seismic vulnerability of air traffic control towers, Nat. Hazards. 90 (2018) 803-822. https://doi.org/10.1007/s11069-017-3072-3.

[8] A. Ghazali, H. Al-Haris Alaydrus, S.C. Alih, M. Vafaei, Seismic fragility of concrete box girder bridges in Malaysia, IOP Conf. Ser. Mater. Sci. Eng. 513 (2019) 012019. 899X/513/1/012019.

[9] S.A. Argyroudis, K.D. Pitilakis, Seismic fragility curves of shallow tunnels in alluvial deposits, Soil Dyn. Earthq. Eng. $\quad 35 \quad$ (2012) 1-12. https://doi.org/10.1016/j.soildyn.2011.11.004.
[10] A. Quilligan, A. O’Connor, V. Pakrashi, Fragility analysis of steel and concrete wind turbine towers, Eng. $\begin{array}{llll}\text { Struct. } & 36 & \text { (2012) 270-282. }\end{array}$ https://doi.org/10.1016/j.engstruct.2011.12.013.

[11] C. Zhou, M. Tian, K. Guo, Seismic partitioned fragility analysis for high-rise RC chimney considering multidimensional ground motion, Struct. Des. Tall Spec. Build. 28 (2019) e1568. https://doi.org/10.1002/tal.1568.

[12] H. Moharrami, M.A. Amini, Seismic vulnerability assessment of process towers using fragility curves, Colourage. 54 (2014) 44-48. https://doi.org/10.1002/tal.

[13] C. Negulescu, T. Ulrich, A. Baills, D.M. Seyedi, Fragility curves for masonry structures submitted to permanent ground displacements and earthquakes, Nat. Hazards. $\quad 74 \quad$ (2014) 1461-1474. https://doi.org/10.1007/s11069-014-1253-X.

[14] A.J. Kappos, G. Panagopoulos, C. Panagiotopoulos, G. Penelis, A hybrid method for the vulnerability assessment of R/C and URM buildings, Bull. Earthq. Eng. 4 (2006) 391-413. https://doi.org/10.1007/s10518006-9023-0.

[15] A.H. Barbat, M.EERI, F. Moya, J.A. Canas, DamageScenariosUrbanZones, Earthq. Spectra. 12 (1996) 24.

[16] M.R.B.C. Abas, Earthquake Monitoring in Malaysia, in: Seism. Risk Semin. Malaysia., Seismological Division Malaysian Meteorological Service, Selangor, 2001: p. 10.

[17] M. Vafaei, S.C. Alih, Q. Abdul Rahman, Drift demands of low-ductile moment resistance frames (MRF) under far field earthquake excitations, J. Teknol. 78 (2016) 8292. https://doi.org/10.11113/jt.v78.5076.

[18] N.N. Fazilan, N.A. Rosman, N.A. Anuar, S.C. Alih, Seismic fragility of low ductile reinforced concrete frame in malaysia, Int. J. Civ. Eng. Technol. 9 (2018) 1559-1571.

[19] S. Aisyah, M. Vafaei, S.C. Alih, K. Aljwim, Seismic Fragility of Tall Concrete Wall Structures in Malaysia under Far-Field Earthquakes, Open Civ. Eng. J. 13 (2019) $140-146$. https://doi.org/10.2174/1874149501913010140.

[20] CSI, ETABS. "V-16": Integrated finite element analysis and design of structures basic analysis reference manual." Computers and Structures Inc (2016).

[21] BS8110-1, Structural use of concrete, Code of practice for design and construction,part 1, British Standard, 1997.

[22] ASCE/SEI 7-10,Minimum Design Loads for Buildings and Other Structures,American Society of Civil Engineers, Reston, Virginia, 2010.

[23] D. Vamvatsikos, C.A. Cornell, Incremental dynamic analysis, Earthq. Eng. Struct. Dyn. 31 (2002) 491-514. https://doi.org/10.1002/eqe.141.

[24] M. Vafaei, A. bin Adnan, A.B.A. Rahman, Seismic performance evaluation of an airport traffic control tower through linear and nonlinear analysis, Struct. Infrastruct. $\quad$ Eng. $10 \quad$ (2014) 963-975. https://doi.org/10.1080/15732479.2013.774030. 
[25] A.S. Whittaker, G.M. Atkinson, J.W. Baker, J.D. Bray, D.N. Grant, R. Hamburger, C. Haselton, P.G. Somerville, Selecting and Scaling Earthquake Ground Motions for Performing Analyses, 15th World Conf. Earthq. Eng. (2012) 1-256. https://doi.org/10.13140/RG.2.1.1769.6800.

[26] M. Vafaei, S.C. Alih, Assessment of seismic design response factors of air traffic control towers, Bull. Earthq. $\quad$ Eng. $14 \quad$ (2016) 3441-3461. https://doi.org/10.1007/s10518-016-0008-3.

[27] F. Berahman, Performance-based seismic evaluation of the Icon Hotel in Dubai, United Arab Emirates, Struct. Des. Tall Spec. Build. 22 (2013) 300-326. https://doi.org/10.1002/tal.688.

[28] M. Vafaei, S.C. Alih, A. Fallah, The accuracy of the lumped plasticity model for estimating nonlinear behavior of reinforced concrete frames under gradually increasing vertical loads, Struct. Concr. (2019) suco. 201800357. https://doi.org/10.1002/suco.201800357.

[29] ASCE/SEI 41-17, Seismic rehabilitation and retrofit of existing buildings, American Society of Civil Engineers (ASCE), Reston, Virginia, 2017.

[30] O.S. Kwon, A. Elnashai, The effect of material and ground motion uncertainty on the seismic vulnerability curves of RC structure, Eng. Struct. 28 (2006) 289-303. https://doi.org/10.1016/j.engstruct.2005.07.010.

[31] W.K. Tso, T.J. Zhu, A.C. Heidebrecht, Engineering implication of ground motion $\mathrm{A} / \mathrm{V}$ ratio, Soil Dyn. Earthq. $\quad$ Eng. $11 \quad$ (1992) 133-144. https://doi.org/10.1016/0267-7261(92)90027-B.

[32] Y. Wen, B. Ellingwood, J. Bracci, Vulnerability function framework for consequence-based engineering, MidAmerica. Earthq. Cent. Proj. DS-4 Report. Univ. Illinois Urbana- Champaign. (2004) 1-101.

[33] Malaysia National Annex To Eurocode 8 - Design Of Structures For Earthquake Resistance, Part 1: General Rules, Seismic Actions And Rules For Buildings, (2017). 